\title{
STRATEGI PENGELOLAAN TAMBAK UDANG VANAME (Litopenaeus vannamei) TERHADAP SEBARAN PENYAKIT PARASITER DI KECAMATAN TANETE RIATTANG TIMUR
}

\author{
Management Strategies Of Vannamei Shrimp \\ (Litopenaeus Vannamei) Ponds Against Parasitic Disease Distribution \\ In Tanete Riattang Timur Subdistrict
}

\author{
Dewi Virgiastuti Jarir 1), Anton 1), Yunarty 1), Suryo Wirawan Anton 2) \\ Fatmah 3), Jayadi 4), Harlina Usman 4) \\ 1) Politeknik Kelautan dan Perikanan Bone \\ 2) Magister Pesisir dan Teknologi Kelautan, UMI Makassar \\ 3) Balai Riset Perikanan Budidaya Air Payau dan Penyuluhan Perikanan, Maros \\ 4) Program Studi: Budidaya Perairan FPIK UMI Makassar \\ Korespondensi:dewivirgiastuti@gmail.com
}

Diterima: tanggal 7 Januari 2020; Disetujui 15 Februari 2020

\begin{abstract}
This research was conducted in August-September 2019 in three (3) subdistricts in Tanete Riattang Timur District, namely Waetuo, Panyula and Toro. The objectives of this study is to formulate priority management strategies for vaname shrimp ponds against the distribution of parasitic diseases. Data were collected by measuring water quality directly at each pond and interviewing shrimp farmers, Head of Marine and Fisheries Agency, fishery extension agents and lecturers of Marine and Fisheries Polytechnics of Bone in the field fish disease. Data were analyzed using both descriptive analysis and Process Hierarchy Analysis (AHP). The results showed that management of vaname shrimp ponds against parasitic diseases distribution was still lack of attention. Vaname shrimp pond management strategies against parasitic diseases distribution in the District of Tanete Riattang Timur, Bone regency, South Sulawesi was directed at the aspect of water quality. According to this study, the aspects to be improved were water quality management, education and experience of farmers, feed management, the use of SPF and SPR certified fries and biosecurity.
\end{abstract}

Keywords : AHP, Management of Vannamei shrimp ponds, parasite

\begin{abstract}
ABSTRAK
Penelitian ini dilaksanakan pada bulan Agustus-September 2019 bertempat di tiga (3) Kelurahan Kecamatan Tanete Riattang Timur yaitu Kelurahan Waetuo, Panyula, dan Toro. Tujuan penelitian ini yaitu Merumuskan prioritas strategi pengelolaan budidaya tambak udang vaname terhadap sebaran penyakit parasiter. Metode yang digunakan dalam pengumpulan data dilakukan dengan pengukuran langsung ke lapangan untuk kualitas air disetiap lokasi tambak dan wawancara terhadap pembudidaya udang, Kepala Dinas Kelautan dan Perikanan, Penyuluh Perikanan, serta akademisi yang berasal dari Dosen Politeknik KP Bone bidang keahlian hama dan penyakit. Analisis yang digunakan untuk mencapai tujuan penelitian adalah analisis deskriptif dan Analisis Hirarki Proses (AHP). Hasil penelitian menunjukkan bahwa strategi pengelolaan tambak udang vaname terhadap sebaran penyakit parasiter di Kecamatan Tanete Riattang Timur Kab. Bone, Sulawesi Selatan diarahkan pada aspek kualitas air. Langkah yang bisa dilakukan yaitu pengelolaan kualitas air, pendidikan dan pengalaman yang dimiliki oleh petambak, pengelolaan pakan, penggunaan benur bersertifikat SPF dan SPR sera biosecurity.
\end{abstract}

Kata kunci: AHP, pengelolaan tambak udang vaname, parasiter 



\section{PENDAHULUAN}

Salah satu pemanfaatan kawasan pesisir yang diharapkan mampu memberikan kontribusi yang cukup besar terhadap pendapatan pemerintah daerah Provinsi Sulawesi Selatan, penyedia lapangan kerja bagi masyarakat pesisir dan perolehan devisa negara yang cukup potensial yaitu usaha budidaya tambak dengan luas tambak tahun 2001 mencapai 86,888 ha dan pada tahun 2005 meningkat menjadi 90,540 ha (Utojo danTangko, 2008).

Kabupaten Bone merupakan salah satu kabupaten di Sulawesi Selatan yang memiliki sepuluh (10) Kecamatan pesisir. Salah satu kecamatan pesisir yang masih bergelut di bidang usaha budidaya udang vaname (Litopenaeus vannamei) yaitu Kecamatan Tanete Riattang Timur.

Usaha budidaya udang vaname merupakan salah satu kegiatan budidaya yang sampai sekarang masih sangat digemari dan digeluti oleh para pelaku usaha perikanan. Seiring dengan berjalannya waktu kegiatan budidaya udang ini semakin berkembang di seluruh Indonesia (Adriyanto dkk, 2013). Salah satu faktor yang menjadikan usaha budidaya udang berkembang yaitu masyarakat pembudidaya udang telah mempunyai prinsip bahwa budidaya udang mampu menjanjikan hasil yang tinggi tetapi juga sebanding dengan biaya dan resiko yang tinggi pula, sehingga bermunculan perorangan maupun kelompok yang membuka lahan untuk melakukan budidaya udang.

Menurut Maimunah dan Kilawati (2015), perkembangan sistem budidaya dari tradisional ke intensif pada mayoritas tambak udang vaname memiliki potensi terhadap peningkatan pencemaran lingkungan. Kurang optimalnya pemanfataan pakan yang berlebihan akan menyebabkan penumpukan bahan organik. Dimana penguraian bahan organik memerlukan oksigen dalam prosesnya, sehingga ketersediaan oksigen bagi biota didalamnya menjadi berkurang. Jika hal ini terjadi secara terus menerus akan menyebabkan kematian bagi udang dan biota lainnya. Bahan pencemaran yang sulit untuk diuraikan oleh mikroorganisme juga menyebabkan penimbunan dan berakibat kerusakan bagi lingkungan yang secara langsung akan mengganggu organisme yang hidup di lingkungan tersebut. Bahan pencemaran organik yang berfungsi 
sebagai pupuk justru merugikan akibat pesisir Kecamatan Tanete Riattang blooming alga sehingga terjadi Timur, Kabupaten Bone, Sulawesi kompetisi oksigen di perairan. Faktor- Selatan. Dimana dalam penelitian ini faktor tersebut merupakan penyebab dilakukan di tiga (3) Kelurahan menurunnya ketahanan tubuh diantaranya yaitu Kelurahan Waetuo, organisme terhadap serangan penyakit Panyula, dan Toro. Hasil sampel karena kualitas lingkungan yang buruk. kemudian diuji di laboratorium Balai Serangan penyakit pada Perikanan Budidaya Air Payau Takalar, organisme akan memberikan dampak Sulawesi Selatan.

negatif terhadap konsumen serta dapat Sampel diambil berdasarkan mempengaruhi harga pasaran. konsep Neuman (2000), jika populasi Pernyataan yang sama juga tergolong kategori kecil, yaitu kurang diungkapkan oleh Ditjen Perikanan dari 1000 populasi, maka sampel Budidaya (2004) bahwa serangan diambil minimal 30 persen dari jumlah penyakit telah mengakibatkan ribuan populasi. Atas dasar pertimbangan hektar tambak tidak digunakan dan tersebut maka jumlah sampel pada tidak produksi lagi, sehingga penelitian yang akan dilakukan mengakibatkan kerugian Negara yang sebanyak 2-3 tambak. Sedangkan untuk cukup besar mencapai 2,5 triliun rupiah udang vaname sampel yang diambil pertahun. Sehingga berdasarkan sebanyak 20 ekor dari seluruh populasi permasalahan yang ada sangat penting udang vaname di masing-masing untuk melakukan penelitian strategi lokasi. Pengambilan sampel sebanyak pengelolaan tambak udang terhadap 20 sudah dianggap mewakili dari sebaran penyakit parasiter sehingga seluruh populasi udang, (Musyaffak para pembudidaya udang mampu dkk, 2010).

menentukan tindakan yang akan Untuk data AHP, pemilihan dilakukan dalam rangka pengendalian. sampel dilakukan secara purposive

\section{MATERI DAN METODE}

Penelitian ini dilakukan selama 2 informasi lebih pada data yang ingin (dua) bulan, yaitu pada bulan Agustus- diketahui yaitu Dinas Kelautan dan September 2019 bertempat di wilayah Perikanan Kab. Bone, Penyuluh 
Perikanan, Petambak, serta Akademisi yang ahli di bidang penyakit. Data yang telah dikumpulkan diolah dengan menggunakan software Expert Choice 9.0 dengan rancangan hirarki pada Gambar 1

Untuk menentukan tingkat prevalensi digunakan rumus sebagai berikut (Musyaffak dkk, 2010) :

$$
\begin{aligned}
& \text { Prevalensi } \\
& =\frac{\sum \text { udang yang terserang penyakit }}{\sum \text { sampel yang diamati }} \times 100
\end{aligned}
$$

Dan untuk menentukan intensitas parasit menggunakan rumus Musyaffak, dkk 2010:

$$
\begin{aligned}
& \text { Intensitas (ind/ekor) } \\
& =\frac{\sum \text { parasit yang ditemukan }}{\sum \text { udang yang terinfeksi }}
\end{aligned}
$$

Perhitungan total bakteri menggunakan metode SNI 7545.1;2009 dimana perhitungan dilakukan dengan cara dihitung secara manual dengan menggunakan colony counter, jumlah koloni yang dihitung menggunakan rumus TPC (Total Plate Count) dengan rumus :

$\mathrm{N}(\mathrm{Cfu} / \mathrm{ml} /)=\mathrm{n}(\mathrm{Cfu} / \mathrm{ml}) / 0,1(\mathrm{ml}) \times 10^{\mathrm{x}}$

Keterangan :

$\mathrm{n}=$ adalah jumlah koloni bakteri dalam plate agar

$10^{\mathrm{x}}=$ seri pengenceran

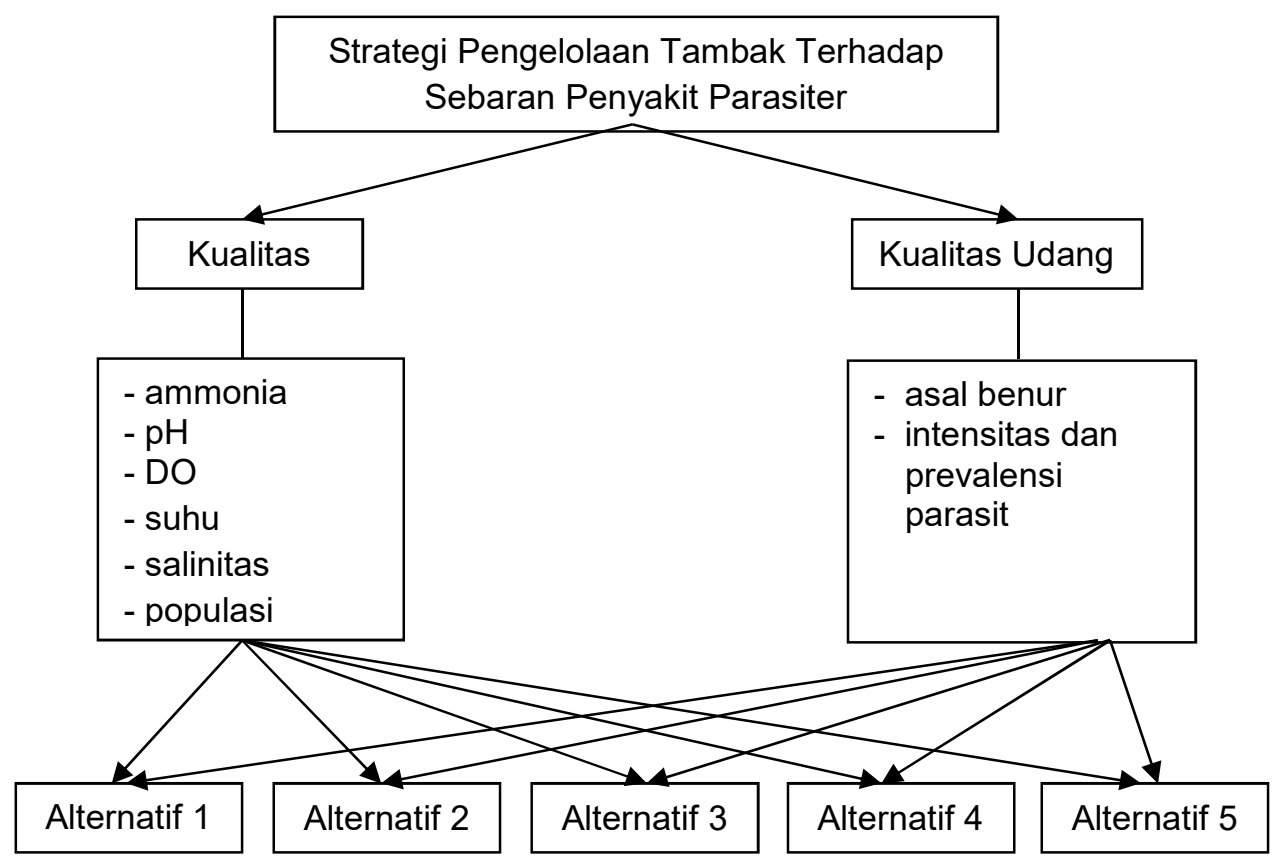

Gambar 1. Rancangan Hirarki Strategi Pengelolaan Tambak Udang Vaname

Dalam kegiatan penelitian, maka diperlukan peralatan dan bahan yang dapat menunjang dalam kegiatan ini. Adapun alat yang digunakan yaitu jala lempar untuk mengambil sampel, botol sampel, plastik packing, dan tabung oksigen. Bahan yang digunakan adalah kuisioner yang telah disusun sesuai 
dengan kebuthan penelitian, sampel (2007) bahwa klekap yang melimpah udang vaname berumur kurang lebih 1 menyebabkan meningkatnya bahan (satu) bulan, oksigen, dan sampel air organik, menurunnya kandungan tambak pemeliharaan udang.

\section{HASIL DAN PEMBAHASAN}

\section{Kajian Kualitas Air}

Hasil nilai kadar ammonia di tiga tambak lokasi penelitian masingmasing Tambak A sebesar 1,6-1,7 ppm, Tambak B sebesar 1,8 ppm, dan Tambak $\mathrm{C}$ bernilai 1,7 ppm. Hasil ini menunjukkan bahwa kadar amonia tambak di Kecamatan Tanete Riattang Timur tidak baik untuk pertumbuhan udang vaname. Hal ini dikarenakan menurut Soetomo (2002), menyatakan bahwa jumlah amonia di dalam tambak akan bertambah sejalan dengan aktifitas proses perombakan dan meningkatnya suhu air. Kandungan amonia di dalam air tidak boleh lebih dari 0,1 ppm atau 0,1 mg/liter. Tingginya kadar ammonia di sampel tambak penelitian diakibatkan karena kurangnya pengontrolan terhadap kegiatan pembuangan klekap (kumpulan alga), dimana klekap yang muncul di permukaan air, bila tidak segera diangkat akan tenggelam kembali ke dasar tambak dan akan mengalami pembusukan. Seperti yang dikatakan oleh Gunarto dan Mansyur oksigen oleh karena proses degradasi bahan organik tersebut. Tambak B sedikit lebih tinggi dibandingkan Tambak A dan Tambak C. Hal ini dikarenakan terjadinya perbedaan frekuensi pergantian air, dimana pada Tambak C melakukan frekuensi pergantian air yang lama yaitu 2 minggu sekali sedangkan untuk Tambak A yaitu 3 hari sekali dan Tambak $\mathrm{C}$ yaitu 1 minggu sekali. Hal ini sesuai dengan pendapat Suwoyo dan Mangampa (2011) bahwa bahan organik menumpuk apabila frekuensi pergantian air semakin lama dilakukan.

Derajat Keasaman pada tambak A berkisar 6-6,3 untuk Tambak B berkisar 5,5-6 dan untuk Tambak $\mathrm{C}$ berkisar 67, perbedaan $\mathrm{pH}$ disetiap lokasi tambak dikarenakan perlakuan yang berbeda tambak udang vaname di Kecamatan Tanete Riattang Timur berkisar 5,5-7. Sedangkan menurut Amri dan Kanna (2008), mengatakan bahwa pH normal untuk tambak udang berkisar antara 69. Dapat dikatakan bahwa kondisi $\mathrm{pH}$ tambak di Kecamatan Tanete Riattang Timur normal, akan tetapi apabila terjadi perubahan $\mathrm{pH}$ secara drastis 
akibat cuaca/iklim maka dilakukan masih dalam kondisi normal untuk pengapuran dengan tujuan untuk budidaya udang vaname yaitu berkisar menetralkan $\mathrm{pH}$. antara $26-30^{\circ} \mathrm{C}$. Hal ini sesuai pendapat

Hasil pengukuran DO pada Haliman dan Adijaya (2005), bahwa Tambak A berkisar 6-6,8. Untuk suhu optimal pertumbuhan udang yaitu Tambak B berkisar antara 6-6,5. 26-32 ${ }^{\circ} \mathrm{C}$. Para pembudidaya di Sedangkan untuk Tambak $\mathrm{C}$ berkisar Kecamatan Tanete Riattang Timur antara 5-6. Dari hasil ke tiga tambak tidak melakukan kegiatan apapun jika yang dijadikan lokasi penelitian di mengetahui suhu air tambak mengalami Kecamatan Tanete Riattang Timur kenaikan atau penurunan karena masih dapat dikatakan dalam kedaan disamping tidak mempunyai data yang baik buat pertumbuhan udang. akurat dengan melakukan pemeriksaan Hal ini sesuai dengan pendapat Farchan secara langsung para petambak juga (2006), mengatakan bahwa DO yang tidak mengetahui bahwa sebenarnya baik untuk pertumbuhan udang adalah ada perlakuan yang dapat dilakukan 4-8 ppm (mg/liter). Kekurangan DO untuk mengatasi masalah kualitas air menjadikan udang mengambang diatas khususnya suhu.

permukaan air dan stress sehingga Salinitas tambak sampel dapat menyebabkan kematian. DO pada penelitian berkisar 25-35 ppt dan tambak budidaya udang vaname masih mengalami peningkatan pada minggu dapat diatasi karena adanya ke V. Hal ini disebabkan karena pada penggunaan kincir sebagai suplay saat tersebut terjadi musim kemarau oksigen akan tetapi penggunaan kincir sehingga meningkatkan penguapan. juga harus dilakukan secara efisien Suhu yang tinggi akan menyebabkan sehingga tidak menimbulkan salinitas air meningkat, karena terjadi pembengkakan biaya. pengentalan akibat penguapan.

Suhu pada Tambak A berkisar Tingginya salinitas air tambak antara 26-30 ${ }^{0} \mathrm{C}$, untuk Tambak $\mathrm{B}$ diduga merupakan salah satu faktor berkisar 28-30 ${ }^{0} \mathrm{C}$, sedangkan untuk yang mempengaruhi laju pertumbuhan Tambak C berkisar $27-30{ }^{\circ} \mathrm{C}$. Suhu udang vaname selama pemeliharaan. secara keseluruhan di Tambak Sedangkan menurut Farchan (2006), Kecamatan Tanete Riattang Timur mengatakan bahwa pertumbuhan udang 

vaname ideal pada salinitas $15-30 \mathrm{ppt}$ (gr/liter). Haliman dan Adijaya (2005) juga menambahkan bahwa salinitas udang muda yang berumur 1-2 bulan memerlukan kadar garam 15-25 ppt (gr/liter) agar pertumbuhannya dapat optimal. Seperti yang terjadi di hampir semua tambak di Kecamatan Tanete Riattang Timur, para petambak pembudidaya meyakini bahwa udang mengeluh bahwa udang yang mereka vanamei lebih baik tumbuhnya pada air pelihara mengalami pertumbuhan payau daripada air laut.

lambat ditandai dengan ukuran udang yang tidak seperti pada biasanya, tidak hanya berpengaruh terhadap kelurahan Kecamatan Tanete Riattang pertumbuhan udang bahkan ada Timur dapat dilihat pada Tabel 1 .

beberapa tambak yang mengalami

Tabel 1. Hasil populasi bakteri vibrio pada masing-masing tambak di setiap kelurahan Kecamatan Tanete Riattang Timur

\begin{tabular}{cccc}
\hline $\begin{array}{c}\text { Nama } \\
\text { Tambak }\end{array}$ & $\begin{array}{c}\text { Jenis } \\
\text { bakteri }\end{array}$ & $\begin{array}{c}\text { Populasi } \\
\text { (CFU/ml) }\end{array}$ & Metode Pemeriksaan \\
\hline Tambak A & Vibrio $\mathrm{sp}$ & $5,5 \times 10^{2}$ & IK 5.4.6.1 Angka Lempeng Vibrio \\
Tambak B & Vibrio $\mathrm{sp}$ & $3,5 \times 10^{1}$ & IK 5.4.6.1 Angka Lempeng Vibrio \\
Tambak C & Vibrio $\mathrm{sp}$ & $2,1 \times 10^{3}$ & IK 5.4.6.1 Angka Lempeng Vibrio \\
\hline
\end{tabular}

Berdasarkan Tabel 1 segi dosis pemberian pakan maupun menunjukkan bahwa setiap tambak dari segi frekuensi pergantian air. memiliki populasi bakteri yang Menurut Tompo (2016) bahwa populasi bervariasi. Dimana tambak $\mathrm{C}$ memiliki bakteri dipengaruhi oleh pola makan jumlah populasi bakteri yang paling dan sisa makanan yang tersisa yang besar dan tambak B memiliki jumlah tidak termanfaatkan oleh udang populasi yang paling rendah. Hal ini sehingga menumpuk pada dasar menandakan bahwa pengelolaan sedimen tambak dan tidak terdapat pengelolaan yang tidak sama terakumulasi pada media air sehingga perlakuannya di setiap tambak baik dari terjadi peningkatan populasi bakteri 
Vibrio pada sedimen tambak karena pemberian probitok selama bakteri tidak ikut terbuang keluar pemeliharaan udang vaname. pada saat dilakukan pergantian air. Kajian Aspek Kualitas Udang Vaname Hal ini ditunjang oleh pendapat Tompo Benur yang digunakan para dan Endang (2008) bahwa sterilisasi petambak di Kecamatan Tanete media air dalam arti harus ada Riattang Timur berasal dari hatchery pergantian air yang dilakukan dalam Benur Kita (Kabupaten Barru) dan CV. petakan perlakuan agar bahan organik Prima (Kabupaten Takalar), akan tetapi terlarut dalam air dan sedimen dapat masih kurangnya perhatian terhadap benar-benar terbuang setelah keberlanjutan yang akan dilakukan pergantian air yang mengakibatkan timbulnya penyakit jadwalnya setiap minggu pergantian khususnya parasit sehingga para air minimal 2 kali. Sedangkan seperti petambak tidak pernah hasil wawancara dan pengamatan yang mempertanyakan tentang keberadaan dilakukan rata-rata pergantian air sertifikat benur tersebut atau pengujian tambak pemeliharaan udang vaname di benur terhadap penyakit yang dibawa Kecamatan Tanete Riattang Timur dari Hatchery. Para petambak hanya tambak A melakukan pergantian air 3 melakukan pemeriksaan secara visual hari sekali dan tambak B melakukan yaitu dengan indikator keaktifan benur pergantian air sebanyak 2 minggu dalam bergerak. Penggunaan benur SPF sekali sedangkan tambak $\mathrm{C}$ melakukan dan SPR adalah meminimalisir resiko pergantian air 1 minggu sekali. Bakteri terserang penyakit (Amri dan Kana, Vibrio sp. tidak boleh berada diatas 2018) kisaran $10^{4} \mathrm{CFU} / \mathrm{mL}$, karena ini Berdasarkan hasil pengamatan dapat menyebabkan kematian pada jenis-jenis ektoparasit yang tambak udang vaname (Muliani, dkk. menginfeksi udang vanamei yang 1996). Salah satu alternatif dibudidayakan di Kecamatan Tanete pencegahan populasi vibriosis adalah Riattang Timur yaitu Zoothamnium sp, pemberian bakteri probiotik. Hal ini Acineta sp, dan Rhabdostyla sp. Data seperti yang dilakukan oleh para hasil prevalensi dan intensitas parasite petambak di Kecamatan Tanete udang vaname di Kecamatan Tanete Riattang Timur dengan melakukan 
Riattang Timur dapat dilihat pada Tabel 2 .

Tabel 2. Hasil prevalensi dan intensitas parasit udang vaname di Kecamatan Tanete Riattang Timur

\begin{tabular}{lcccc}
\hline \multicolumn{1}{c}{ Jenis Ektoparasit } & $\begin{array}{c}\text { Yang terinfeksi } \\
\text { (ekor) }\end{array}$ & $\begin{array}{c}\text { Parasit } \\
\text { (individu) }\end{array}$ & $\begin{array}{c}\text { Prevalensi } \\
(\%)\end{array}$ & $\begin{array}{c}\text { Intensitas } \\
\text { (ind/ekor) }\end{array}$ \\
\hline Zoothamnium $\mathrm{sp}$ & 3 & 150 & 20 & 50 \\
Acineta $\mathrm{sp}$ & 3 & 30 & 20 & 10 \\
Rhabdostyla $\mathrm{sp}$ & 2 & 5 & 13,3 & 2,5 \\
\hline
\end{tabular}

Berdasarkan Tabel 2 pada tingkat infeksi sedang yaitu 6-55 menunjukkan bahwa semua organ ind/ekor (William dan Bunkley, 1996). diperiksa pada udang vaname terserang Nilai parameter kualitas air yang ektoparasit dengan nilai prevalensi sebelumnya telah dibahas, secara $13,3 \%$ sampai dengan $20 \%$ dan nilai keseluruhan menunjukkan bahwa di intensitas mencapai 2,5 sampai dengan Kecamatan Tanete Riattang Timur 50 ind/ekor yang menginfeksi bagian masih ideal dalam pertumbuhan udang tubuh luar udang. Sehingga dari ketiga vaname.

jenis parasit ini dapat dikatakan bahwa Untuk jenis parasit yang kriteria prevalensi parasit berada pada menyerang udang vaname di tingkat serangan sering yang berarti Kecamatan Tanete Riattang Timur infeksi sering yaitu 29-10\% sedangkan dapat dilihat pada Gambar 2.

untuk kriteria intensitas parasit berada

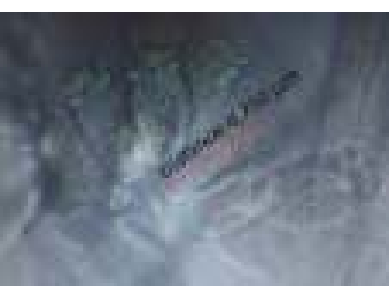

(a)

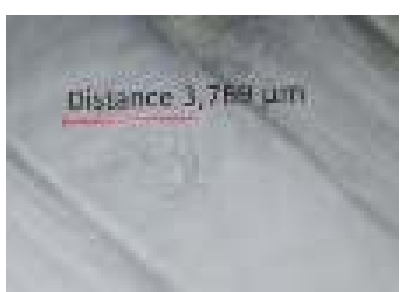

(b)

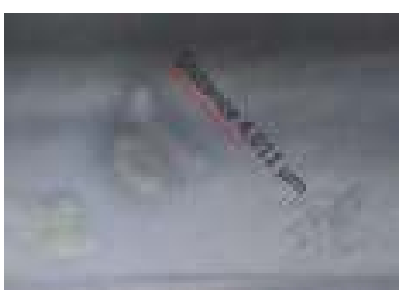

(c)

Gambar 2. Jenis parasit yang menyerang udang vaname (a) Zoothamnium sp, (b) Rhabdostyla sp, (c) Acineta sp

Pengelolaan tambak terhadap penelitian ini yaitu kualitas air media sebaran penyakit parasiter seperti yang pemeliharaan, kedua parasit pada sudah dijelaskan sebelumnya bahwa penelitian ini yaitu kondisi udang memilki tiga lingkaran aspek yang vaname dan ketiga yaitu inangnya atau sangat penting dimana ketiga aspek itu udang vaname itu sendiri. Setelah adalah lingkungan yang dalam dilakukan analisis prioritas dari ke lima 
alternatif yang ada, diperoleh nilai bahwa, alternatif yang diprioritaskan Pengelolaan Kualitas Air (0,29), untuk mencapai pengelolaan tambak Pengelolaan Pakan $(0,16)$, Penggunaan udang vaname terhadap penyakit yang Benur Bersertifikat SPF dan SPR disebabkan oleh jenis parasit adalah $(0,16)$, Penerapan Bbiosecurity $(0,15)$ dengan pengelolaan kualitas air. Untuk dan Pendidikan dan Pelatihan yang hirarki pengelolaan tambak udang Dimiliki Oleh Petambak $(0,23)$ dengan vaname terhadap sebaran penyakit nilai inconsistency<0.05. Menunjukkan parasiter dapat dilihat pada Gambar 3 .

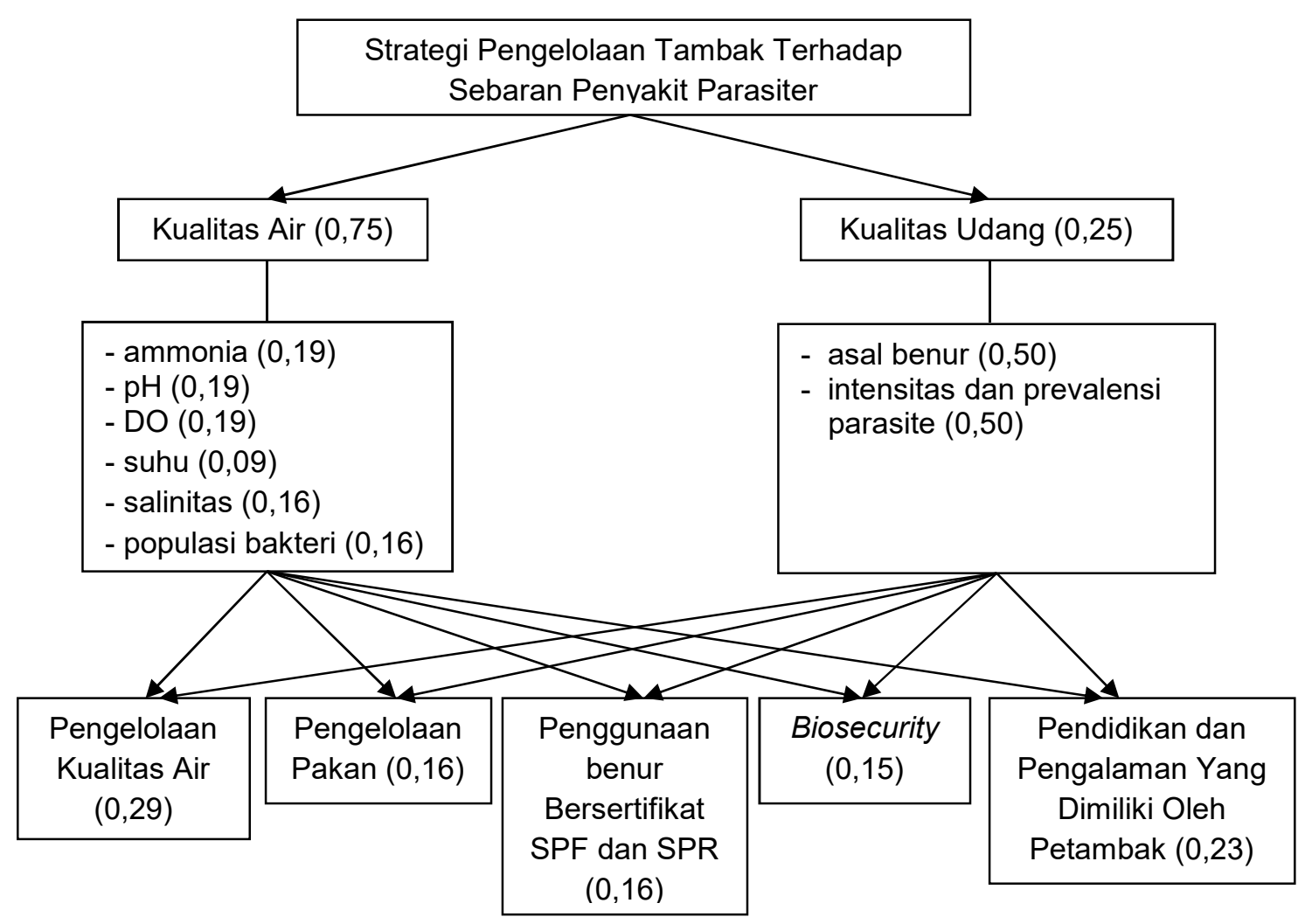

Gambar 3. Hirarki Pengelolaan Tambak Pengelolaan Tambak Udang Vaname Terhadap Sebaran Penyakit Parasiter

Adanya pengelolaan kualitas air alternatif kedua yaitu pendidikan dan diharapkan dapat mengatur kondisi pelatihan yang dimiliki oleh petambak. lingkungan yang dibutuhkan oleh Prioritas tersebut jika dijalankan udang vaname untuk bertahan hidup, dengan baik, maka akan sangat mengalami pertumbuhan serta terhindar menunjang pengelolaan yang telah dari serangan penyakit khususnya direncanakan karena akan dapat parasit. Setelah pengelolaan kualitas air 
membantu dalam mengelola kualitas air dengan baik.

\section{KESIMPULAN}

Berdasarkan hasil pembahasan maka dapat ditarik kesimpulan yaitu strategi pengelolaan tambak udang vaname terhadap sebaran penyakit parasiter di Kecamatan Tanete Riattang Timur Kab. Bone, Sulawesi Selatan diarahkan pada aspek kualitas air. Langkah yang bisa dilakukan yaitu pengelolaan kualitas air, pendidikan dan pengalaman yang dimiliki oleh petambak, pengelolaan pakan, penggunaan benur bersertifikat SPF dan SPR serta biosecurity.

\section{SARAN}

Para pemilik usaha harus menerapkan Standar Operasional Prosedur (SOP) dalam pencegahan timbulnya parasit diantaranya ketersediaan peralatan kualitas air dan penerapan Biosecurity serta perlunya mendapatkan pendampingan lebih dari segi penyuluhan dan pelatihan dikarenakan kurangnya pemahaman tentang pengendalian penyakit parasit dan perlu dilakukan penelitian lanjutan mengenai seberapa besar pengaruh infeksi parasit terhadap pertumbuhan udang vaname dengan sistem intensif.

\section{UCAPAN TERIMA KASIH}

Penulis mengucapkan terima kasih kepada Kecamatan Tanete Riattang Timur, Kabupaten Bone dan Laboratorium Balai Perikanan Budidaya Air Payau Takalar, Sulawesi Selatan.

\section{DAFTAR PUSTAKA}

Adriyanto, F., Efani, A., dan Riniwati, H. 2013. Analisis Faktorfaktor Produksi Usaha Pembesaran Udang Vanname (Litopenaeus vannamei) di Kecamatan Paciran Kabupaten Lamongan Jawa Timur ;Pendekatan Fungsi CobbDouglass. Jurnal ECSOFIM. Vol. 1, No. 1, 2013 :hal 82-96.

Afrianto dan E. Liviawaty. 1992. Pengendalian Hama Penyakit Ikan. Kanisius. Yogyakarta

Amri, K dan Kanna, I. 2008. Budidaya Udang Vaname Secara Intensif, Semi Intensif dan Tradisional. PT Gramedia Pustaka Utama. Jakarta.

Direktorat Jenderal Perikanan Budidaya. 2004. Uji Teknologi Budidaya Udang Bebas Penyakit Bercak Putih. Mina Bahari, 3 (02): hal16-17

Farchan. 2006. Teknik Budidaya Udang Vaname. BAPPLSekolah Tinggi Perikanan. Serang

Gunarto, dan Mansyur, A. 2007. Budi daya Udang Vannamei (Litopenaues vannamei) di Tambak Dengan Padat Tebar Berbeda Menggunakan Sistem Pemupukan Susulan. Jurnal 
Riset Akuakultur. Vol. 2, No.1 Tahun 2007.

Haliman, R. W. dan D.S. Adijaya. 2005. Budidaya Udang Vannamei. Penebar Swadaya. Jakarta. hal. 36-39

Handajani, H. dan Samsundari, S. 2005. Parasit dan Penyakit Ikan. UMM Press : Malang.

Lin, Y.C. \& Chen, J.C. 2003. Acute Toxicity Of Nitrite On Litopenaeus Vannamei (Boone) Yuwanaes At Different Salinity Levels. Aquaculture, 224: 193-201.

Maimunah, Y dan Kilawati, Y. 2015. Kualitas Lingkungan Tambak Intensif Litopenaeus vannamei Kaitannya Dengan Prevalensi Penyakit White Spot Syndrome Virus. Research Journal of Life Science. Volume 02, No. 01, April 2015.

Muliani, M.I.Madeali, A.Tompo. 1996. Prosiding Seminar Nasional Mikrobiologi Kelautan dan Biomediasi, Ujung Pandang. Hal 192-194

Musyafak, M., Abida, I.W., dan Muhson, F.F. 2010. Analisa Tingkat Prevalensi dan Derajat Infeksi Parasit pada Ikan Kerapu Macan (Ephinephilus fuscoguttatus) di Lokasi Budidaya Berbeda. Jurnal Kelautan. Vol. 3, No. 1, April 2010 :hal 82-90.

Neuman W, Laurence. 2000. Social Research Methods. Qualitative and Quantitative Approaches. Allyn and Bacon. Boston.

SNI 7545.1:2009. Metode Identifikasi Bakteri pada Ikan secara Konvensional. Bagian 1:
Edwardsiella ictaluri, Badan Standarisasi Nasional, $10 \mathrm{hlm}$.

Soetomo, M. H. A. 2000. Teknik Budidaya Udang Windu. Sinar Baru Algensindo. Bandung.

Suwoyo, HS. dan Mangampa M. 2011. Aplikasi Probiotik Dengan Konsentrasi Berbeda Pada Pemeliharaan Udang Vaname (Litopenaeus vannamei). Prosiding Forum Inovasi Teknologi Akuakultur 2010. Hal 239-247.

Tompo, A. 2016. Kajian Populasi Bakteri Vibrio sp. pada Tambak Budidaya Udang Vaname (Litopenaeus vannamei) Sistem Semi Intensif Dengan Presentase Pemberian Pakan yang Berbeda. Octopus. Volume 5 Nomor 1.

Tompo, A. Dan Endang S. 2008. Dinamika populasi bakteri vibrio sp. Di tambak aplikasi bakteri untuk pencegahan penyakit pada budidaya udang windu. Prosiding Semnaskan V Hasil Penelitian perikanan dan Kelautan th 2008, Jokjakarta. UGM 24 Juli 2008

Utojo dan A.M. Tangko. 2008. Status Masalah dan Alternatif Pemecahan Masalah pada Pengembangan Budidaya Udang Vanname (Litopenaeus vannamei) di Sulawesi Selatan. Media Akuakultur, Vol. 3, Nomor 2 Tahun 2008.

Williams, E.H. and Bunkley-Williams, L. 1996. Parasites of Offshore Big Game Fishes of Puerto Rico and the Western Atlantic. Sportfish Disease Project. University of Puerto Rico. 